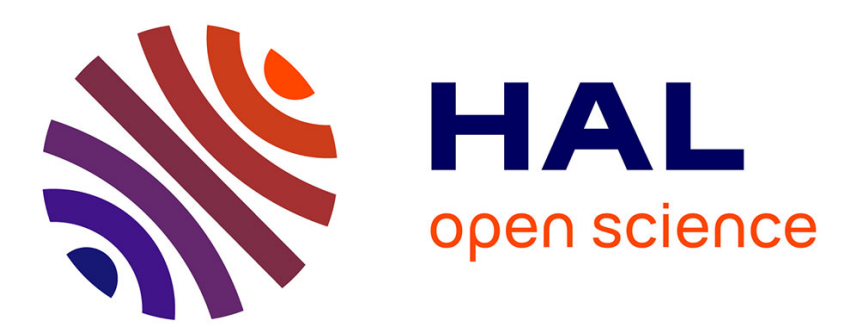

\title{
Ecohydraulic quantification of hydropeaking alterations by the use of hydrosignatures: a two scale approach
}

\author{
Y. Le Coarer, B. Testi, J. Beguin
}

\section{To cite this version:}

Y. Le Coarer, B. Testi, J. Beguin. Ecohydraulic quantification of hydropeaking alterations by the use of hydrosignatures: a two scale approach. La Houille Blanche - Revue internationale de l'eau, 2017, 2, pp.15-19. 10.1051/lhb/2017012 . hal-01720434

\section{HAL Id: hal-01720434 \\ https://hal.science/hal-01720434}

Submitted on 1 Mar 2018

HAL is a multi-disciplinary open access archive for the deposit and dissemination of scientific research documents, whether they are published or not. The documents may come from teaching and research institutions in France or abroad, or from public or private research centers.
L'archive ouverte pluridisciplinaire $\mathbf{H A L}$, est destinée au dépôt et à la diffusion de documents scientifiques de niveau recherche, publiés ou non, émanant des établissements d'enseignement et de recherche français ou étrangers, des laboratoires publics ou privés. 


\title{
Ecohydraulic quantification of hydropeaking alterations by the use of hydrosignatures: a two scale approach
}

\author{
Yann LE COARER, Baptiste TESTI, Jérémy BEGUIN
}

Irstea d'Aix en Provence/UR RECOVER, yann.lecoarer@irstea.fr

\begin{abstract}
Hydropeaking flow fluctuations can affect aquatic fauna in various ways, depending on the river's morphological characteristics. We have developed a method for quantifying hydropeaking events by drawing up hydrosignatures. In a given flow, a hydrosignature quantifies the hydraulic diversity in any area/part of the aquatic space defined by either volume or area percentages on a depth and current velocity cross grid. When a two-dimensional hydraulic model for hydropeaking events is available, in a given reach, a comparative hydrosignature index can be calculated between the hydrosignature of the present time step and the initial hydrosignature, or between two hydrosignatures separated by a constant time interval. This method is useful to determine where major changes have occurred along a river, and to classify hydropeaking intensities. This approach can be used to analyse the level of hydraulic transformation of an entire reach but does not focus on the sides of the channel inhabited by the juvenile fish, which are particularly exposed to the effects of flow fluctuations. Juvenile habitats can be defined by suitability indexes which are attributed to hydraulic classes of hydrosignatures. The total weighted usable area of a juvenile habitat can be calculated at all the time steps in a hydraulic simulation by partitioning any hydraulic mesh into hydraulic classes. An index quantifying the damage to juvenile populations can then be defined by calculating the maximum change in habitat area observed during the hydropeaking event.
\end{abstract}

Key-words: fish habitat, juvenile fish, hydraulic simulation.

\section{Utilisation d'hydrosignatures pour quantifier les effets ecohydrauliques des éclusées : une démarche à deux échelles}

\begin{abstract}
RÉSUMÉ. - Selon la morphologie d'un cours d'eau, une même variation de débit suite à une éclusée peut avoir des conséquences diverses sur les communautés aquatiques en place. C'est pourquoi, nous proposons une méthode pour quantifier l'effet des éclusées à l'aide d'hydrosignatures. A un débit donné, pour une partie de l'espace aquatique, une hydrosignature quantifie la diversité hydraulique comme la répartition en pourcentages d'aires ou de volumes de verticales hydrauliques reparties dans des classes croisées de vitesses moyennes et de hauteurs d'eau. Lorsque l'on dispose d'une modélisation hydraulique bidimensionnelle d'un tronçon de rivière en éclusées, celui-ci peut être analysé en sous-tronçons de longueurs fixes, en utilisant un système de repérage en coordonnées curvilignes. Pour tout sous-tronçon, un indice de comparaison d'hydrosignatures, peut être calculé entre un pas de temps donné et l'instant initial ou entre deux instants séparés par une durée fixée. Cette méthode permet de localiser les parties d'un cours d'eau où les variations hydrauliques sont les plus importantes, mais aussi de classifier des intensités de variations hydrauliques entre cours d'eau soumis à des éclusées. Cependant, si cette approche permet de qualifier l'entièreté d'un chenal, elle ne permet pas d'analyser spécifiquement les variations hydrauliques en bordures, là où les jeunes stades de poissons sont particulièrement mis en danger par les variations hydrauliques locales. Cet habitat spécifique peut être défini par des coefficients de préférences pour des classes hydrauliques. Ces coefficients peuvent être calculés d'une façon similaire à la construction des courbes de préférences classiques à partir d'hydrosignatures d'échantillonnages par pêches électriques. Pour un tronçon de cours d'eau, l'aire pondérée utile de cet habitat peut être calculée pour chaque pas de temps d'une simulation hydraulique d'éclusée. Ces calculs sont effectués en partitionnant les mailles hydrauliques en sous- mailles n'appartenant qu'à une classe hydraulique. Un indice qualifiant le risque pour les jeunes stades de poissons peut être défini comme le maximum de variation de surface pondérée lors de l'éclusée.
\end{abstract}

Mots-clés : habitat poisson, juvenile, alevin, modélisation hydraulique.

\section{INTRODUCTION}

Quantifying and predicting the ecological effects of hydropeaking events is important to adopt efficient measures to protect the aquatic biodiversity of hydrosystems. The ecological consequences of hydropeaking events depend strongly on the interactions between these events and the local morphological characteristics [Vanzo et al., 2015]. We present here a method to analyse the theoretical impact on fish populations of hydropeaking events with similar flow ramping rates $\Delta Q(t)\left[\mathrm{m}^{3} \mathrm{~s}^{-1} \mathrm{~min}^{-1}\right]$ and similar base-to-peak flow variations in river reaches with different morphological channel characteristics.

\section{WHAT IS A HYDROSIGNATURE ?}

Hydrosignatures were originally developed for ecohydraulic modelling purposes in order to quantify the hydraulic richness [Le Coarer, 2007]. 
At a given flow rate, any part of an aquatic space can be described by a continuous set of verticals giving the depth $(D)$ and the mean velocity $(V)$. After defining hydraulic classes corresponding to ranges of depths and mean velocities, the aquatic space can then be partitioned into hydroelements, i.e., continuous sets of verticals belonging to a single hydraulic class. The percentages of the various hydraulic classes present in a given aquatic space in terms of volumes or areas constitute the hydrosignature of that space (Figure 1). For instance, to calculate the area percentage of a given hydraulic class, it suffices to add together the areas of all the hydroelements belonging to this hydraulic class and then calculate the percentage in comparison with the total aquatic area.

To calculate a hydrosignature, it suffices to have a hydraulic description based on the verticals $(V, D)$ obtained either by performing measurements or using conventional hydraulic models. Methods of calculating hydrosignatures have been developed, based on the most widely used modes of description using non-spatialized data, cross-sections and meshing approaches [Le Coarer, 2005; Le Coarer 2007; Scharl and Le Coarer, 2005]. Free software can be obtained for this purpose from http://hydrosignature.irstea.fr.

\section{HYDROSIGNATURES FOR HYDROPEAKING CLASSIFICATION}

When a two-dimensional hydraulic model for hydropeaking events is available, hydrosignatures can be calculated at any time step in the simulation. A comparative hydrosignature index IHSC $[1,1]$ [Scharl and Le Coarer, 2005] can be calculated between the hydrosignature of the present time step and the initial hydrosignature $\operatorname{IHSC}\left(t_{0}, t_{n}\right)$. This index gives a value ranging between 0 and 100 , which will be all the higher as the hydraulic difference is greater. It requires that the two hydrosignatures to be compared should be of the same kind (area or volume) and they have to be partitioned in the same hydraulic grid with constant intervals between depth classes and between velocity classes.

The maximum value $\operatorname{IHSC\operatorname {max}}\left(t_{0}, t_{n}\right)$ of this index during a hydropeaking event qualifies the intensity of this event as in terms of the overall changes in the hydraulic parameters. Similar indexes can also be calculated between two hydrosignatures separated by a constant time interval, and the maximum value $\operatorname{IHSC\operatorname {max}}\left(t_{n}, t_{n}+\Delta t\right)$ can then be determined. A similar approach can be applied, using energy hydrosignatures obtained by replacing the velocity coordinate in the grids by $\frac{V^{2}}{2 \cdot g}$, where $\mathrm{g}$ is the acceleration due
to gravity.

If a finer approach is required, the river can be split into any number of sub-reaches of the same length with a curvilinear system of coordinates. A hydrosignature can be calculated for any sub-reach at any time step (Figure 2).

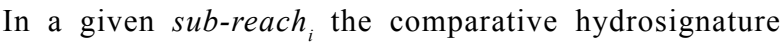
indexes previously defined can be calculated either between the hydrosignature of the present time step and the initial hydrosignature $\operatorname{IHSC}\left(t_{0}, t_{n}\right.$, sub-reach $\left._{i}\right)$, or between two hydrosignatures separated by a constant time interval $\operatorname{IHSC}\left(t_{n}, t_{n}+\Delta t\right.$, sub-reach $\left.{ }_{i}\right)$. This method is a useful means

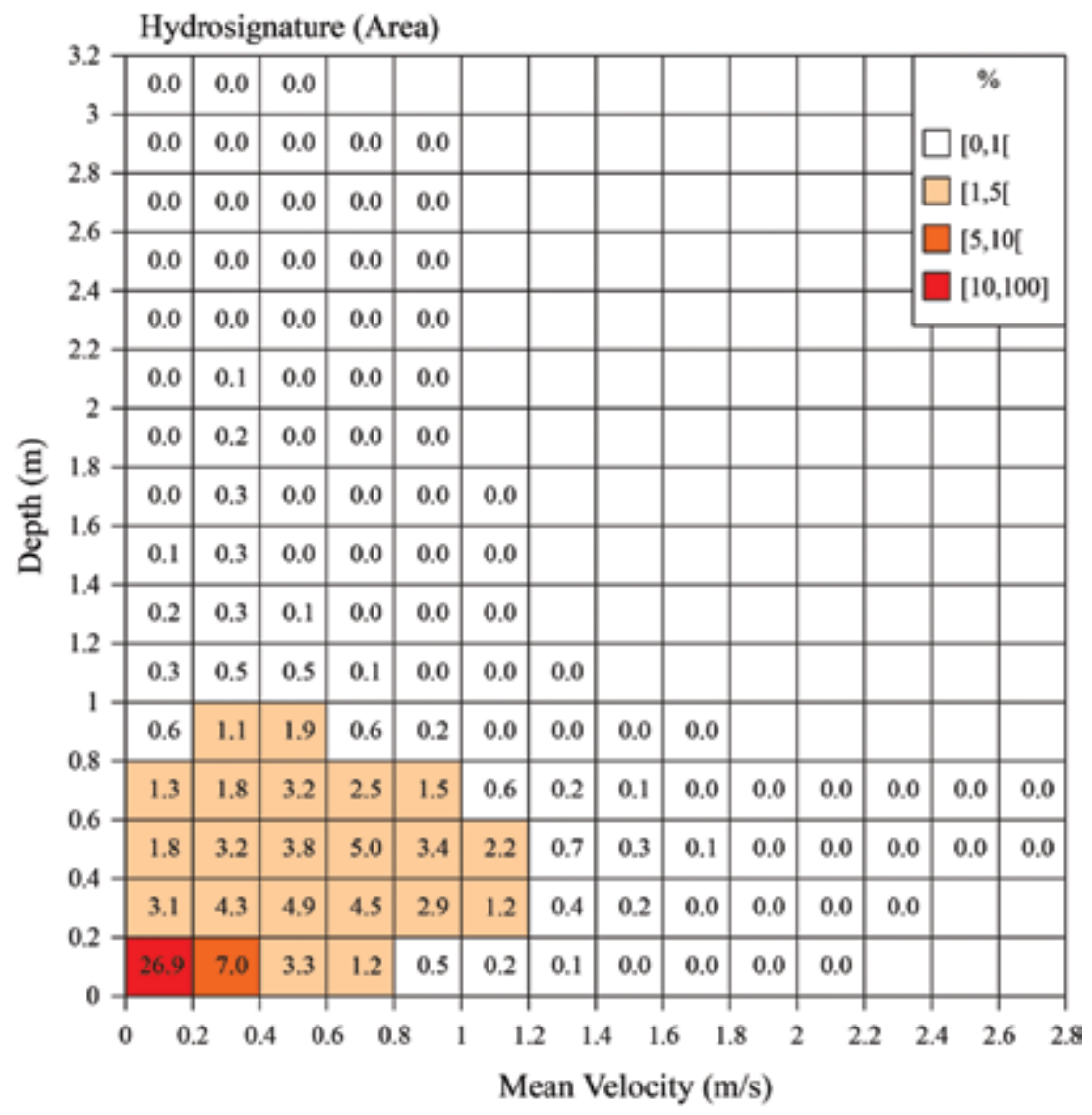

Figure 1 : A hydrosignature: a grid in the mean velocity versus depth $(V, D)$ coordinate system giving the percentages of the hydraulic classes, with the blocks in the grid coloured differently, depending on these percentages for easy readability. Here we have the area hydrosignature of a $10 \mathrm{~km}$ stretch of the lower Durance river, with an instream flow of $9.8 \mathrm{~m} 3 . \mathrm{s}^{-1}$. 


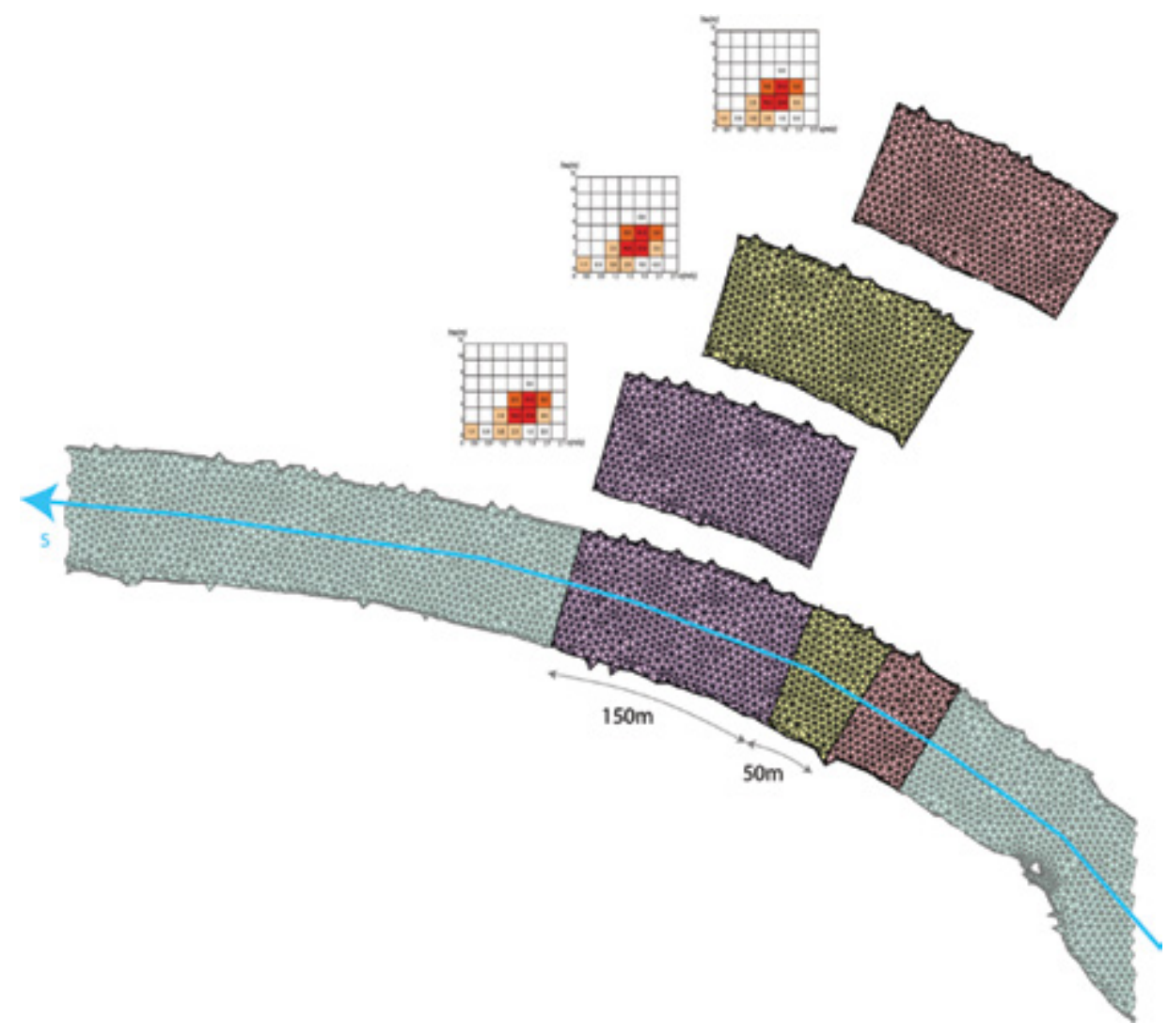

Figure 2 : Splitting a reach: At a given time step in a hydraulic simulation, a reach is split into sub-reaches $150 \mathrm{~m}$ in length every $50 \mathrm{~m}$ on a curvilinear abscissa and the hydrosignatures of all the sub-reaches are calculated.

of determining where the major changes occurred along the river and for classifying hydropeaking intensities among different case studies, not only on terms of global IHSCmax values but also in terms of the IHSC statistics on all the sub-reaches of interest.

Comparing hydropeaking case studies requires collecting a wide range of hydraulic data sets in order to define a universal hydrosignature, a hydraulic grid that can be applied in all circumstances.

It is worth mentioning that a similar method consisting in calculating hydrosignatures for each of the sub-reaches and comparing them with that of the whole reach can be applied in order to identify a suitably representative location for carrying out hydrobiological sampling operations.

\section{ANALYSING JUVENILE FISH HABITATS DURING HYDROPEAKING EVENTS}

The juvenile members of fish populations are those which are the most sensitive to the effects of sudden changes in the flow, mainly because juveniles tend to inhabit the sides of the channels, where there is a greater risk of being stranded. In order to quantify the changes in these habitats as exactly as possible, it is necessary to use a finer scale than that of the whole channel. In a given fish species and size class, the juvenile habitat can be defined by suitability indexes, which are attributed to hydraulic classes and normalized in order to obtain values ranging between 0 and 1 . These values can be obtained by performing similar calculations to those used to draw up suitability preference curves [Bovee et al., 1988; Lamouroux et al., 1999] based on use-to-availability ratios, which are applied to the hydrosignatures of electrofishing sample units.

If a $2 \mathrm{D}$ hydraulic model is available, the juvenile habitat corresponding to each flow simulated can be mapped using a hydrosignature method consisting of partitioning any hydraulic mesh into hydroelements. After performing this operation, each finite meshing element is delimited by 3 pairs of "measured" or interpolated vertical depth/ mean velocity data belonging to the same hydraulic class. To generate the interpolated vertical data required for the hydroelement partitioning operations, linear interpolations are performed on the following variables: $(X, Y, Z, D, V)$ applied to the original vertical data involved in the hydraulic simulation (the so-called "measured" values).

The principle used to deal with a simple case where a single hydraulic class suffices to define the juvenile habitat is shown in Figure 3. In the case of multiple indexed hydraulic classes, on similar lines to what occurs with the Instream Flow Incremental [Bovee, 1982] method, the juveniles' weighted usable area (WUA) can be calculated in each hydraulic simulation. This calculation can be carried out by taking the product of each index multiplied by the corresponding percentage of the hydrosignature: the sum of these products will then have to be multiplied by the total wet area to obtain $W U A(Q)$. It is worth mentioning that the velocity and depth are not assumed to be independent variables: they are always taken together when using the hydrosignature approach.

In practice, because classical 2D hydraulic models are not designed for ecohydraulic analysis, grid elements are often too large for a precise analysis. To improve precision, we separate the wet and dry parts of the grid elements which are at the river limits. In the case shown in Figure 4, a mesh 


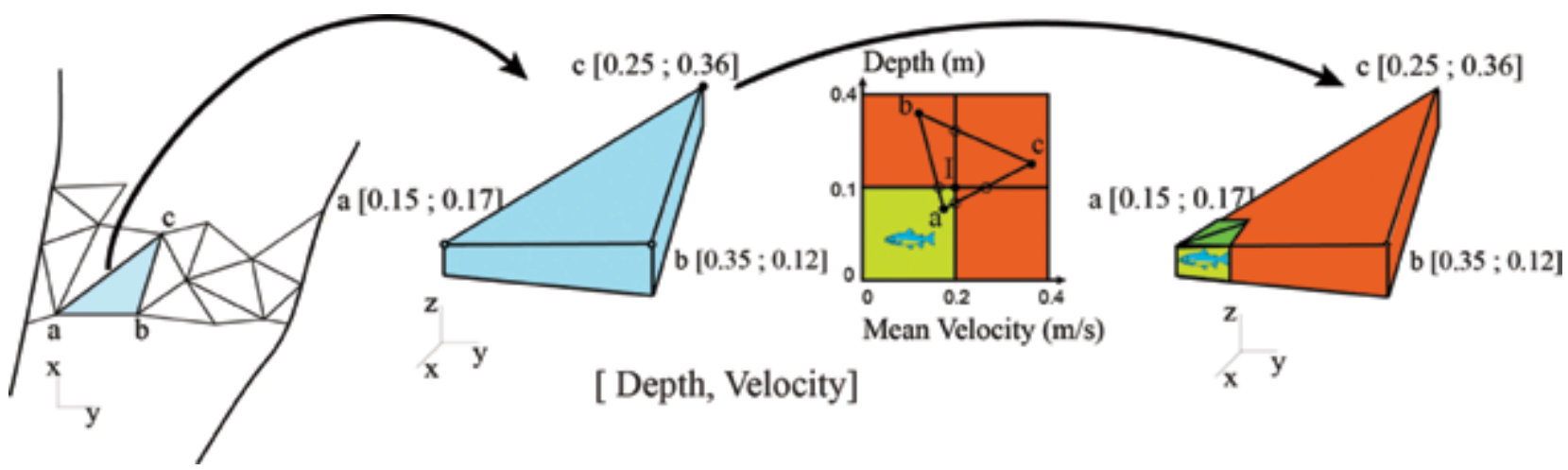

Figure 3 : Diagram on the horizontal plane of an irregular triangular network and the decomposition of a finite meshing element into hydroelements, showing the existence of a juvenile fish habitat defined by a hydraulic depth of less than $0.1 \mathrm{~m}$ and a mean velocity of less than $0.2 \mathrm{~m} \cdot \mathrm{s}^{-1}$.
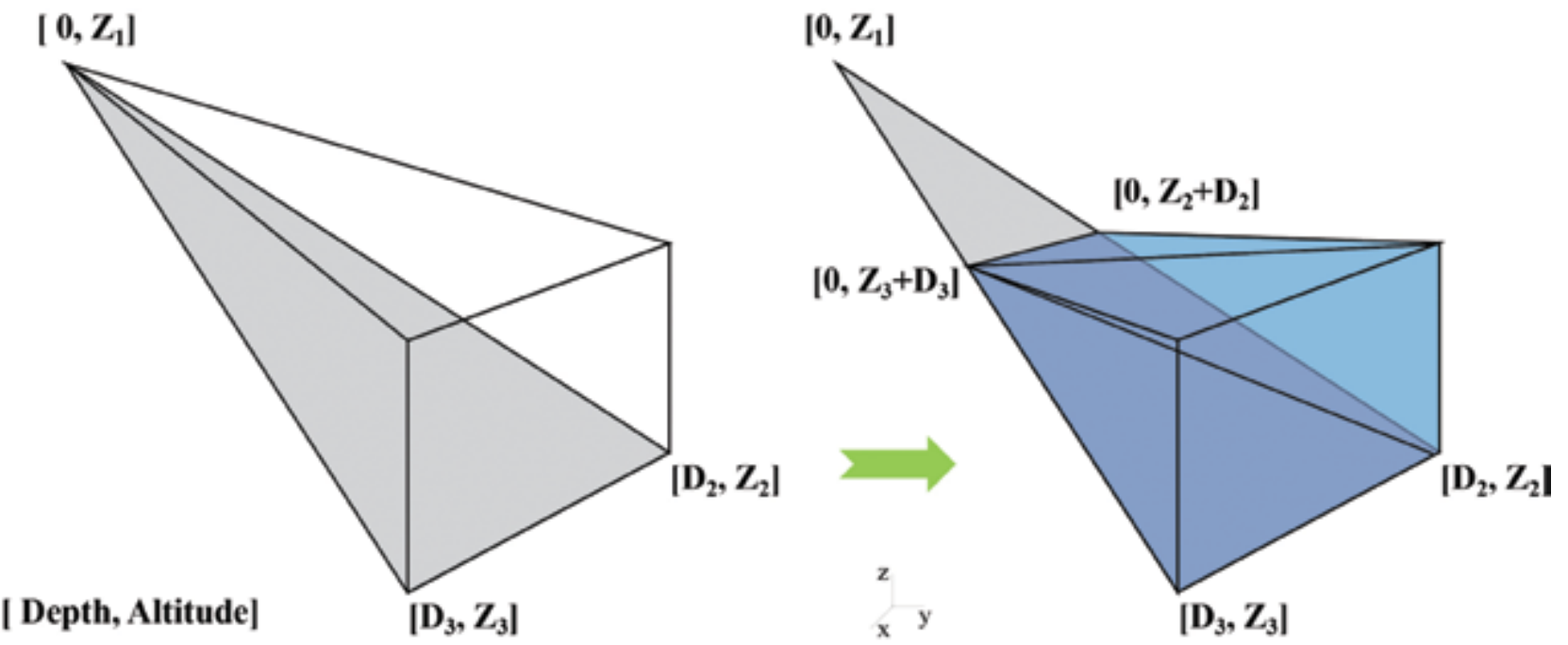

Figure $4:$ A case where a partly emergent mesh was partitioned into wet and dry meshes, using the definition of the free surface obtained from the water verticals.

was partitioned into wet and dry meshes by using water verticals to define the free surface, and linear interpolations were performed to define the limits of the wet river bed.

Calculations of this kind were performed on a $7.5 \mathrm{~km}$ long stretch of the lower Durance river based on a $9.5 \mathrm{~m}^{3} \mathrm{~s}^{-1}$ TELEMAC-2D simulation. In this case, the wet surface was overestimated by $17 \%$ before these calculations were performed.

A $9.5 \mathrm{~m}^{3} \mathrm{~s}^{-1}$ TELEMAC-2D simulation was also performed on a $7.5 \mathrm{~km}$ stretch of the lower Durance river, corresponding to a juvenile habitat belonging to a hydraulic class defined by a water depth of less than $0.1 \mathrm{~m}$ and a mean velocity of less than $0.2 \mathrm{~m} . \mathrm{s}^{-1}$. The results obtained here showed that the regions in which the depth was less than $1 \mathrm{~cm}$ accounted for $30 \%$ of the total area of the juvenile habitat in question. One should therefore not omit to specify the minimum depth of the juvenile habitat compatible with the actual presence of fish.

An index quantifying the damage to juvenile populations can be obtained by dividing the maximum habitat area by the minimum habitat area observed during the artificial release of flow.
Based on the studies we have conducted on the Rhine, the Durance and the Creuse, when the flow increases, the modelled area of the juvenile habitat will generally decrease in single-thread reaches and increase in braided reaches.

More complex spatial analyses of the juvenile habitat can be conducted by examining the changes in the patterns of connectivity occurring between the various habitat patches during hydropeaking events. The loss of habitat incurred during the event due to the destruction of patches can thus be deduced by comparing the final area of the habitat with the initially available area.

\section{CONCLUSIONS}

The findings presented here were simply intended to show how this new hydrosignature approach can be used to quantify the impact of hydropeaking on the natural environment, either by describing the overall hydraulic effects of sudden changes in flow or by analysing the changes in the juvenile fish populations' habitats. With the methods presented here, the morphological characteristics of the 
rivers studied can be taken into account as long as a $2 \mathrm{D}$ hydraulic model is available.

Hydrosystems' responses to the effects of hydropeaking certainly depend on many other factors in addition to those studied here, such as hydrological and thermal factors and the complex responses of the whole food chain, which will also have to be studied in order to obtain a complete picture of these effects.

In future studies, many processes will have to be taken into account to estimate the specific effects of hydropeaking on juvenile fish populations. We have not included the granulometric composition or the substrate clogging in this study, for example, whereas Hauer et al. [2014] have established that the substrate size has to be taken into account when analysing the risk of fish being stranded. During transient regimes, small-amplitude waves and the intensification of turbulent processes due to changes in the flow rates can also affect the behaviour of young fish inhabiting the riversides. These factors will no doubt be difficult to analyse because fish will react differently depending on their species, their size and their circadian rhythms. Experimental studies are therefore required in order to obtain the lacking biological data. Hydraulic modelling on finer scales will also be needed, including the granulometry and descriptive parameters other than those generally used so far. The use of technological devices such as airborne LiDARs is already helping to obtain finer descriptions of river's topography and bathymetry.

Many efforts still remain to be made in order to protect hydrosystems from adverse anthropic effects by improving our knowledge via multidisciplinary studies and international concertation.

\section{ACKNOWLEGMENTS AND THANKS}

The technical support of G. Carrel F. Morat and D.Von Gunten is gratefully acknowledged.

\section{REFERENCES}

BoveE K.D. (1982) - A guide to stream habitat analysis using the Instream Flow Incremental Methodology. FWS/OBS-82/26, U.S. Department of the Interior, Fish and Wildlife Service, Office of Biological Services, Washington, D.C.

BoveE K.D. (1988) - Use of the instream flow incremental methodology to evaluate influences of microhabitat variability on trout populations in four Colorado streams. 68th Annual conference, Western Association of Fish and Wildlife Agencies, Albuquerque 31 p.

LE COARER Y. (2005) - "HydroSignature" software for hydraulic quantification. Proceedings, Final COST 626 European Aquatic Modelling Network meeting in Silkeborg, Denmark 19-20 May 2005 (Eds Harby A., Baptist M., Duel H., Dunbar M., Goethals P., Huusko A., Ibbotson A., Mader H., Pedersen M., Schmutz S. \& Schneider M.) 193-203

Le CoARer Y. (2007) - Hydraulic signatures for ecological modelling at different scales. Aquat. Ecol. 41 451-459

Hauer C., Unfer G., Holzapfel P., Haimann M. \& Habersack H. (2014) - Impact of channel bar form and grain size variability on estimated stranding risk of juvenile brown trout during hydropeaking. Earth Surf. Processes \& Landforms. 39(12) $1622-1641$

Lamouroux N., Capra H., Poullly M. \& Souchon Y. (1999) Fish habitat preferences in large streams of southern France. Freshwat. Biol. 42(4) 673-687

SCHARL A. \& Le COARER Y. (2005) - Morphohydraulic quantification of non spatialized datasets with the "Hydrosignature" software. In Proceedings, Final COST 626 European Aquatic Modelling Network meeting in Silkeborg, Denmark 19-20 May 2005 (Eds Harby A., Baptist M., Duel H., Dunbar M., Goethals P., Huusko A., Ibbotson A., Mader H., Pedersen M., Schmutz S. \& Schneider, M.) 313-326

Vanzo D., Zolezzi G. \& Siviglia A. (2015) - Eco-hydraulic modelling of the interactions between hydropeaking and river morphology. Ecohydrology 10.1002/eco.1647: n/a-n/a 